\title{
Literature survey on epidemiology and pathology of gangliocytic paraganglioma
}

Yoichiro Okubo', Megumi Wakayama1', Tetsuo Nemoto', Kanako Kitahara', Haruo Nakayama², Kazutoshi Shibuya ${ }^{1 *}$, Tomoyuki Yokose ${ }^{3}$, Manabu Yamada ${ }^{1}$, Kayoko Shimodaira', Daisuke Sasai ${ }^{1}$, Takao Ishiwatari ${ }^{1}$, Masaru Tsuchiya ${ }^{4}$ and Nobuyuki Hiruta'

\begin{abstract}
Background: Although gangliocytic paraganglioma (GP) has generally been regarded as a neuroendocrine tumor, its origin remains unclear. We therefore aimed to investigate the details of this disease by carefully analyzing and extracting common features of the disease as presented in selected publications.

Methods: We searched for English and Japanese cases of GP using the PubMed and IgakuChuoZasshi databases on August 2010. We then extracted and sampled raw data from the selected publications and performed appropriate statistical analyses. Additionally, we evaluated the expression of hormone receptors based on our previously reported case.

Results: 192 patients with GP were retrieved from the databases. Patient ages ranged from 15 y to 84 y (mean: $52.3 \mathrm{y}$ ). The gender ratio was 114:76 (male to female, 2 not reported). Maximum diameter of the tumors ranged from $5.5 \mathrm{~mm}$ to $100 \mathrm{~mm}$ (mean: $25.0 \mathrm{~mm}$ ). The duodenum $(90.1 \%, 173 / 192)$ was found to be the most common site of the disease. In 173 patients with duodenal GP, gastrointestinal bleeding (45.1\%, 78/173) was found to be the most common symptom of the disease, followed by abdominal pain $(42.8 \%, 74 / 173)$, and anemia $(14.5 \%, 25 / 173)$. Rate of lymph node metastasis was 6.9\% (12/173). Our statistical analysis indicated that significant differences were found for gender between GP within the submucosal layer and exceeding the submucosal layer. Furthermore, our immunohistochemical evaluation showed that both epithelioid and pancreatic islet cells showed positive reactivity for progesterone receptors.

Conclusions: Our literature survey revealed that there were many more cases of GP exceeding the submucosal layer than were expected. Meanwhile, our statistical analyses and immunohistochemical evaluation supported the following two hypotheses. First, vertical growth of GP might be affected by progesterone exposure. Second, the origin of GP might be pancreatic islet cells. However, it is strongly suspected that our data have been affected by publication bias and to confirm these hypotheses, further investigation is required.
\end{abstract}

\section{Background}

Gangliocytic paraganglioma (GP) was first reported as ganglioneuroma by Dahl et al. in 1957 [1] and Kepes et al. named this disease entity as GP in 1971 [2]. Although GP has generally been regarded as a neuroendocrine tumor, some authors have reported that GP is a hamartoma developing in misplaced embryonic pancreatic tissue [3-5]. Despite these investigations, the origin

\footnotetext{
* Correspondence: kaz@med.toho-u.ac.jp

'Department of Surgical Pathology, Toho University School of Medicine, 6-

11-1 Omori-Nishi, Ota-Ku, Tokyo, 143-8541, Japan

Full list of author information is available at the end of the article
}

of GP remains unclear. However, a few cases of GP showing lymph node metastasis are well known [Table 1], and we previously reported such a case [6]. That case prompted us to survey publications of GP to investigate mechanisms for GP. In the present study, we searched literature databases and selected publications of GP in English and Japanese from 1957 to the early trimester of 2010 in order to investigate details of the disease.

Few studies reported the epidemiology, pathology, and clinical characteristics of the disease. We then evaluated the details of the disease by carefully analyzing and

\section{Biomed Central}


Table 1 Duodenal gangliocytic paraganglioma with lymph node metastasis

\begin{tabular}{|c|c|c|c|c|c|c|c|}
\hline Reference & Year & $\begin{array}{l}\text { Age } \\
\text { (years) }\end{array}$ & Sex & Chief Clinical presentation & $\begin{array}{l}\text { Size } \\
(\mathrm{mm})\end{array}$ & Operation & Follow up (months) \\
\hline $\begin{array}{l}\text { Buchler et al. } \\
\text { [50]. }\end{array}$ & 1985 & 50 & Male & Gastrointestinal bleeding & 30 & Surgical intervention & NED 20 \\
\hline Inai et al. [51]. & 1989 & 17 & Male & Hematoemesis & 20 & PD & NED 32 \\
\hline $\begin{array}{l}\text { Hashimoto et al. } \\
\text { [52]. }\end{array}$ & 1992 & 47 & Male & Incidental findings & 65 & PD & NED 14 \\
\hline $\begin{array}{l}\text { Takabayashi et al. } \\
\text { [53]. }\end{array}$ & 1993 & 63 & Female & Abdominal pain & 32 & PPPD & NED 24 \\
\hline $\begin{array}{l}\text { Dookhan et al. } \\
\text { [24]. }\end{array}$ & 1993 & 41 & Male & Abdominal pain & 25 & $\begin{array}{l}\text { Additional surgical } \\
\text { intervention }\end{array}$ & $\begin{array}{l}\text { Recurrence } 11 \text { years after first surgical } \\
\text { intervention }\end{array}$ \\
\hline $\begin{array}{l}\text { Sundararajan et } \\
\text { al. [54]. }\end{array}$ & 2003 & 67 & Female & Incidental findings & 50 & PD & NED 9 \\
\hline Bucher et al. [55]. & 2004 & 31 & Female & Anemia, subclinical jaundice & 30 & PPPD & NED 44 \\
\hline Wong et al. [25]. & 2005 & 49 & Female & Melena & 14 & PPPD & NED 12 \\
\hline $\begin{array}{l}\text { Witkiewicz et al. } \\
{[36] \text {. }}\end{array}$ & 2007 & 38 & Female & Abdominal pain & 15 & PPPD & NR \\
\hline Mann et al. [56]. & 2009 & 17 & Female & $\begin{array}{l}\text { Abdominal pain, vomiting, } \\
\text { weight loss }\end{array}$ & NR & PPPD & NR \\
\hline Okubo et al. [6] & 2010 & 61 & Male & Epigastralgia, tarry stool & 30 & PPPD & NED 6 \\
\hline Saito et al. [46]. & 2010 & 28 & Male & $\begin{array}{l}\text { Gastrointestinal bleeding, } \\
\text { anemia }\end{array}$ & 17 & PD & NED 12 \\
\hline
\end{tabular}

NR: not reported, PD: pancreatoduodenectomy, PPPD: pylorus-preserving pancreaticoduodenectomy

NED: no evidence of disease

There were twelve cases of gangliocytic paraganglioma with lymph node metastasis.

extracting common features of the disease as presented in these selected publications.

\section{Methods}

We searched English and Japanese cases of GP published from 1957 to the early trimester of 2010 using the PubMed http://www.ncbi.nlm.nih.gov/pubmed/ and IgakuChuoZasshi http://www.jamas.or.jp/ databases on August 2010 by conducting a search of "gangliocytic paraganglioma" with case report options as an additional tool. As a result, 4574 English and 27 Japanese publications were retrieved.

We checked the abstracts and 73 English and 24 Japanese (total 97) publications were regarded as cases of GP and 4504 publications were excluded.

Since this disease entity has been reported under other names, prior to Kepes et al. naming it as a GP [2], such as "ganglioneuroma", "non-chromaffin paraganglioma", and "paraganglioneuroma", we checked the references of 97 selected publications.

Finally, we added 8 publications as GP reports because they met the following criteria:

1. The characteristic three components could be confirmed in the manuscript or a figure.

2. The paper was cited in other publications as a GP report.

These 105 publications contained reports on 192 patients with GP. In the present study, we conducted a non-systematic literature review using 173 patients with duodenal GP.

We extracted and sampled raw data from the selected publications, such as clinical findings (age, sex, clinical symptoms, operation method, and outcome), histopathological findings (site, maximum diameter of the tumor, diagnostic rate from biopsy before operation, the depth of the tumor invasion, and with or without lymph node metastasis), and immunohistochemical findings.

In addition, we performed appropriate statistical analyses using the extracted data. Statistical analyses were performed using the non-parametric Mann-Whitney U test or Chi-square test.

Differences were considered significant at $\mathrm{P}<0.05$.

Additionally, we evaluated gender differences based on the results of our statistical analyses. Moreover, we evaluated the expression of hormone receptors in relation to estrogen and progesterone based on our previously reported case [6].

Finally, we declare that our study may be affected by publication bias because it comprises a cumulating case series.

\section{Result}

\section{Overall findings}

192 patients with GP were retrieved from the PubMed and IgakuChuoZasshi databases. Patient ages ranged from $15 \mathrm{y}$ to $84 \mathrm{y}$ (mean: $52.3 \mathrm{y}$ ). The gender ratio was 
114:76 (male to female, 2 not reported). Maximum diameter of the tumors ranged from $5.5 \mathrm{~mm}$ to $100 \mathrm{~mm}$ (mean: $25.0 \mathrm{~mm})$. The duodenum $(90.1 \%, 173 / 192)$ was found to be the most common site of the disease, followed by the low-level spinal cord $(2.1 \%, 4 / 192)$ [7-10], respiratory system $(2.1 \%, 4 / 192)$ [11-14], jejunum $(1.6 \%$, $3 / 192)[5,15,16]$, and esophagus $(1.0 \%, 2 / 192)[17,18]$. There were individual cases involving the stomach [5], appendix [19], retromediastinum [20], pancreas [21], and mature teratoma [22] (constituent of the lesion), as well as a case of double focus in the duodenum and pancreas [23] $(0.5 \%, 1 / 192$, respectively). In accordance with these findings, the present study focuses on the duodenal lesion, which represents the site for the overwhelming majority of cases of the disease.

\section{Clinical findings}

173 patients with duodenal GP were retrieved from the PubMed and IgakuChuoZasshi databases. Patient ages ranged from $15 \mathrm{y}$ to $84 \mathrm{y}$ (mean: $52.6 \mathrm{y}$ ). The gender ratio was 102:69 (2 not reported).

Gastrointestinal bleeding $(45.1 \%, 78 / 173)$ was found to be the most common symptom of the disease among the symptoms reported in the papers, followed by abdominal pain $(42.8 \%, 74 / 173)$, and anemia $(14.5 \%, 25 / 173)$. In contrast, biliary obstruction was extremely rare $(4.6 \%, 8$ / 173). The follow-up period ranged from 12 months to 96 months, and no death from GP was reported. With the exception of a patient that had part of a previous tumor at the initial operation [24], no recurrence has been reported. There is only one report of a patient who underwent radiotherapy after surgical intervention [25]. 15 patients underwent an endoscopic procedure for removal [26-40], and one patient required additional surgical intervention due to the presence of a tumor residue following her first endoscopic intervention [36].

\section{Histopathological findings}

Histopathological findings from forceps biopsies performed prior to surgical intervention were described in 35 patients. Among these cases, 4 patients were correctly diagnosed as GP, 24 patients did not show evidence of tumor cells (specimens did not contain tumor cells), and 7 patients were diagnosed or suspected of having a different neuroendocrine tumor (3 carcinoid tumors, 2 paragangliomas, 1 ganglioneuroma, and 1 case involving atypical cells).

The maximum diameter of the tumors ranged from $5.5 \mathrm{~mm}$ to $100 \mathrm{~mm}$ (mean: $24.2 \mathrm{~mm}$ ). The depth of the tumor invasion was described in 108 patients, comprising 42 patients with submucosal invasion, 62 with muscularis propria invasion, and 4 with connective tissue beneath the muscularis propria. In summary, 42 patients had GP within the submucosal layer and 66 patients had GP exceeding the submucosal layer. Moreover, 12 of these patients showed lymph node metastasis that involved one submucosal lesion [Table 1].

\section{Immunohistochemical findings}

Representative findings for each of the three characteristic components of tumor cells are as follows. In epithelioid cells, neuron specific enolase (NSE) showed the highest positive rate $(93.9 \%, 77 / 82)$, followed by synaptophysin $(90.0 \%, 36 / 40)$, pancreatic polypeptide (PP; $89.7 \%, 70 / 78)$, somatostatin $(81.8 \%, 63 / 77)$, chromogranin-A $(67.4 \%, 60 / 89)$, cytokeratins $(48.3 \%, 28 / 58)$, and serotonin $(22.0 \%, 13 / 59)$.

In spindle-shaped cells, S-100 protein showed the highest positive rate $(94.2 \%, 98 / 104)$, followed by NSE (84.0\%, 63/75), and synaptophysin $(64.7 \%, 22 / 34)$.

In ganglion-like cells, synaptophysin showed the highest positive rate $(94.3 \%, 33 / 35)$, followed by NSE $(84.0 \%$, $63 / 75)$, somatostatin $(44.1 \%, 30 / 68)$, and PP $(22.2 \%, 16 /$ 72 ). Immunohistochemical findings are summarized in Table 2 .

\section{Comparative analysis of clinicopathological findings}

To determine significant factors associated with the progression of the tumor, the following comparative analyses were carried out.

When we employed evidence of metastasis as an indicator of progression, a significant difference was found only for the ages of patients among the clinicopathological findings concerning those with and without lymph node metastasis (Mann-Whitney $U$ test: $p=0.01$ ), and patients with metastasis were significantly younger than those without metastasis. In contrast, no significant differences were found in the maximum diameter of the tumors or gender when comparing patients with and without lymph node metastasis (Mann-Whitney $U$ test: $\mathrm{p}=0.10$ or Chi-square test: $\mathrm{p}=0.55$, respectively).

These results are summarized in Table 3.

Furthermore, comparisons of clinicopathological findings revealed significant differences for both gender and the rate of lymph node metastasis in patients when comparing GP within the submucosal layer and exceeding the submucosal layer (Chi-square test: $\mathrm{p}=0.02$, 0.03, respectively). Namely, patients having GP exceeding the submucosal layer were predominantly female and showed a higher rate of lymph node metastasis. These results are summarized in Table 4.

However, no significant differences were found for the maximum diameter of the tumor or the age of a patient between males and females. In addition, Spearman's rank correlation coefficient was calculated to assess any potential relationship between the maximum diameter of the tumors and ages of patients, but no significant relationships were found. 
Table 2 Immunohistochemical findings for each of the three characteristic components of the tumor

\begin{tabular}{|c|c|c|c|}
\hline & Epithelioid cells & Spindle-shaped cells & Ganglion-like cells \\
\hline$S-100$ & $3.8 \%(4 / 104)$ & $94.2 \%(98 / 104)$ & $9.3 \%(9 / 97)$ \\
\hline Synaptophysin & $90.0 \%(36 / 40)$ & $64.7 \%(22 / 34)$ & $94.3 \%(33 / 35)$ \\
\hline Chromogranin A & $67.4 \%(60 / 89)$ & $7.2 \%(6 / 83)$ & $15.4 \%(12 / 78)$ \\
\hline Neuron specific enolase & $93.9 \%(77 / 82)$ & $84.0 \%(63 / 75)$ & $84.0 \%(63 / 75)$ \\
\hline Cytokeratins & $48.3 \%(28 / 58)$ & $4.0 \%(2 / 50)$ & $3.9 \%(2 / 51)$ \\
\hline Vimentin & $14.3 \%(1 / 7)$ & $50.0 \%(2 / 4)$ & $0.0 \%(0 / 6)$ \\
\hline Neuron fiber & $20.9 \%(14 / 67)$ & $66.7 \%(44 / 66)$ & $24.6 \%(16 / 65)$ \\
\hline Pancreatic polypeptide & $89.7 \%(70 / 78)$ & $0.0 \%(0 / 72)$ & $22.2 \%(16 / 72)$ \\
\hline Somatostatin & $81.8 \%(63 / 77)$ & $8.7 \%(6 / 69)$ & $44.1 \%(30 / 68)$ \\
\hline Serotonin & $22.0 \%(13 / 59)$ & $0.0 \%(0 / 55)$ & $16.7 \%(9 / 54)$ \\
\hline Vasoactive intestinal polypeptide & $12.1 \%(4 / 33)$ & $12.9 \%(4 / 31)$ & $9.7 \%(3 / 31)$ \\
\hline Glucagon & $6.4 \%(3 / 47)$ & $0.0 \%(0 / 44)$ & $2.4 \%(1 / 42)$ \\
\hline Gastrin & $5.9 \%(4 / 68)$ & $0.0 \%(0 / 64)$ & $0.0 \%(0 / 63)$ \\
\hline Insulin & $2.2 \%(1 / 46)$ & $0.0 \%(0 / 41)$ & $0.0 \%(0 / 42)$ \\
\hline
\end{tabular}

Positive or negative findings from immunohistochemistry in 173 extracted duodenal gangliocytic paraganglioma are summarized.

\section{Immunohistochemical evaluation of female sex hormone receptors}

Since the results mentioned above suggested that progression of the tumor has some relationship with sex hormone activities, we evaluated the expression of hormone receptors in relation to estrogen and progesterone based on our previously reported case of GP. As a result, epithelioid cells in both primary and metastatic foci showed strongly positive reactivity for progesterone receptors and negative reactivity for estrogen receptors [Figure 1]. In addition, normal pancreatic islet cells showed strongly positive reactivity for progesterone receptors and weakly positive reactivity for estrogen receptors [Figure 1].

\section{Discussion}

We collected as many publications written in English or Japanese involving GP and examined them to extract characteristic features of the tumor as presented in clinical and histopathological findings.

We focused on determining the significant factors associated with the progression of the tumor. Here we discuss the clinical, histopathological, and immunohistochemical findings in reference to matters that emerged from our research.

In the present study, we found gastrointestinal bleeding as the most common symptom, followed by abdominal pain. This fact has been previously accepted and our data confirm it. All patients without autopsies and having clinically incidental focus had surgical interventions, including 15 patients with endoscopic intervention. Indeed, one patient required additional surgical intervention due to a residue of the tumor at her first endoscopic procedure [36], while other patients showed a good outcome without recurrence or metastasis. Furthermore, there was no record of a patient dying from GP, and patients with this tumor, therefore, have an extremely good prognosis. However, one patient has been reported as showing a recurrence due to a residue of a previous tumor at his initial surgical intervention [24]. Accordingly, we emphasize the importance of both a histopathological assessment of extensive tumor components at the surgical margin

Table 3 Comparison of clinicopathological findings between patients with and without lymph node metastasis

\begin{tabular}{|c|c|c|c|}
\hline & $\begin{array}{l}\text { Patients with lymph node } \\
\text { metastasis }\end{array}$ & $\begin{array}{l}\text { Patients without lymph node } \\
\text { metastasis }\end{array}$ & Statistical analysis \\
\hline Number of patients & 12 & 161 & \\
\hline Age (years) & 17 to 67 (mean: 43.5) & 15 to 84 (mean: 53.4) & $\begin{array}{l}\text { Significant difference was found } \\
\text { (Mann-Whitney } U \text { test: } p=0.01 \text { ) }\end{array}$ \\
\hline $\begin{array}{l}\text { Maximum diameter of the tumor } \\
\qquad(\mathrm{mm})\end{array}$ & 5.5 to 65 (mean: 29.8) & 10 to 100 (mean: 23.5) & $\begin{array}{l}\text { No significant difference was } \\
\text { found } \\
\text { (Mann-Whitney } U \text { test: } p=0.10 \text { ) }\end{array}$ \\
\hline Gender (male to female) & $6: 6$ & 96:63 (2 not reported) & $\begin{array}{l}\text { No significant difference was } \\
\text { found } \\
\text { (Chi-square test: } p=0.55 \text { ) }\end{array}$ \\
\hline
\end{tabular}

A significant difference was found for the ages of patients with and without lymph node metastasis (Mann-Whitney $U$ test: $p=0.01$ ), and patients with lymph node metastasis were significantly younger than those without lymph node metastasis. In contrast, no significant differences were found for maximum diameter of the tumor or gender in patients with and without lymph node metastasis (Mann-Whitney $U$ test: $p=0.10$ or Chi-square test: $p=0.55$, respectively). 
Table 4 Comparison of clinicopathological findings between GP within and exceeding the submucosal layer

\begin{tabular}{|c|c|c|c|}
\hline & $\begin{array}{l}\text { Gangliocytic paraganglioma within } \\
\text { the submucosal layer }\end{array}$ & $\begin{array}{l}\text { Gangliocytic paraganglioma } \\
\text { exceeding the submucosal layer }\end{array}$ & Statistical analysis \\
\hline Number of patients & 42 & 66 & \\
\hline Age (years) & 28 to 84 (mean: 54.1 ) & 15 to 73 (mean: 50.0) & $\begin{array}{l}\text { No significant difference was found } \\
\text { (Mann-Whitney } U \text { test: } p=0.23 \text { ) }\end{array}$ \\
\hline $\begin{array}{l}\text { Maximum diameter of } \\
\text { the tumor }(\mathrm{mm})\end{array}$ & 5.5 to 65 (mean: 21.7) & 10 to 100 (mean: 26.8) & $\begin{array}{l}\text { No significant difference was found } \\
\text { (Mann-Whitney } U \text { test: } p=0.18 \text { ) }\end{array}$ \\
\hline $\begin{array}{l}\text { Gender (male to } \\
\text { female) }\end{array}$ & $29: 13$ & $30: 36$ & $\begin{array}{l}\text { Significant difference was found } \\
\quad \text { (Chi-square test: } p=0.02 \text { ) }\end{array}$ \\
\hline $\begin{array}{l}\text { Rate of lymph node } \\
\text { metastasis }\end{array}$ & $2.4 \%(1 / 42)$ & $16.7 \%(11 / 66)$ & $\begin{array}{l}\text { Significant difference was found } \\
\quad \text { (Chi-square test: } p=0.03 \text { ) }\end{array}$ \\
\hline
\end{tabular}

Significant differences were found for gender and the rate of lymph node metastasis between patients with GP within the submucosal layer and exceeding the submucosal layer (Chi-square test: $p=0.02,0.03$, respectively).

and imaging examinations to monitor for recurrence or metastasis after the operation.

Although one patient received irradiation after surgical intervention [25], we maintain that patients without residual tumor require no adjuvant therapy because no recurrence or metastasis has been reported in such patients. By contrast, it is still unclear whether a residual tumor can be controlled by irradiation or chemotherapy alone without surgical intervention.

The immunohistochemical findings on the tumors need consideration since the identification of three cellular components are essential for diagnosis. Epithelioid and ganglion-like cells showed a high positive rate for several kinds of immunohistochemical neuroendocrine markers, such as synaptophysin, chromogranin A, and NSE. In addition, epithelioid cells showed a high positive rate for PP. In contrast, spindle-shaped cells had the highest positive rate for S-100. These results are consistent with other previous publications. Furthermore, positive rates for each hormone, such as somatostatin, serotonin, gastrin, glucagon, and insulin in epithelioid cells, were significantly different and the meaning of this finding is worth investigating. However, these extracted immunohistochemical findings should be regarded as hints or suggestions because it is thought that results involving negative data have not been described in previous publications. In fact, our previous case report did not describe the
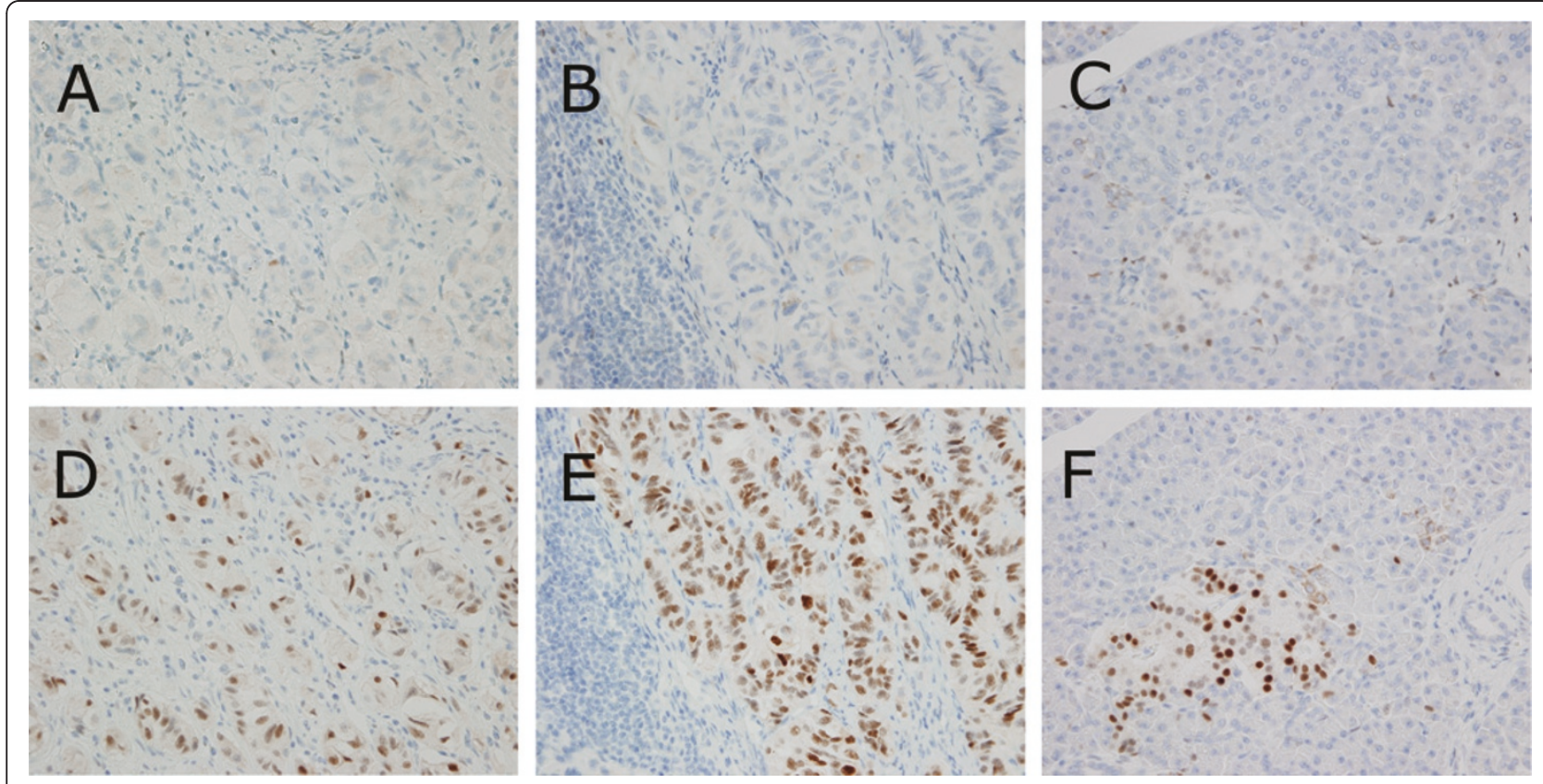

Figure 1 Photomicrographs showing immunohistochemistry for estrogen and progesterone receptors. (A and B) Epithelioid cells in both primary and metastatic foci were negative for estrogen receptors $(\times 400)$. (C) Pancreatic islet cells showed a weakly positive reactivity for estrogen receptos $(\times 400)$. ( $D$ and $E)$ Epithelioid cells in both primary and metastatic foci showed a strongly positive reactivity for progesterone receptors $(\times 400)$. (F) Pancreatic islet cells showed a strongly positive reactivity for progesterone receptors $(\times 400)$. 
immunohistochemical evaluation of each hormone according to negative reactivity.

Incidentally, we previously tried to establish the immunohistochemical prognostic indicators of GP using bcl-2, p53, and Ki-67, which are acceptable prognostic indicators in several kinds of neuroendocrine tumors [41-44]. However, all of these indicators showed a negative reactivity.

Unfortunately, there were no other cases of GP that included an immunohistochemical evaluation using bcl2 and p53, and the value of these factors as prognostic indicators of GP remains unclear.

In contrast, two cases without lymph node metastasis were described with the Ki-67 labeling index in GP $[45,46]$. However, both showed extremely low Ki-67 labeling index values. Therefore, we suggest that immunohistochemical evaluation using Ki-67 may have a limited prognostic value in GP.

Finally, we gained insight into the progression of GP tumors and related factors. It has been accepted that GP usually arises from the submucosal or muscular layer, which may make the diagnosis difficult using a forceps biopsy prior to surgical intervention. In fact, we revealed that the diagnostic rate by biopsy before surgical intervention was only $11.4 \%(4 / 35)$. In addition, we showed that many more cases of GP exceeding the submucosal layer were reported $(61.1 \%, 66 / 108)$ than expected, and GP exceeding the submucosal layer is a risk factor for lymph node metastasis. These facts emphasize the importance of imaging examinations prior to surgical interventions.

It is interesting to note that significant differences were found for gender between GP within the submucosal layer and exceeding the submucosal layer. On the basis of our investigation, a hypothesis emerged that asserted no significant relationship for gender and that female gender induces vertical growth of the tumor. To confirm part of our hypothesis, we focused on femalespecific factors and initially evaluated tumor cells immunohistochemically using anti-estrogen and progesterone receptor antibodies. As a result, our immunohistochemical evaluation revealed that epithelioid cells showed positive reactivity for the progesterone receptor. Furthermore, some investigators reported that progesterone regulates neural differentiation $[47,48]$. These facts suggest that the vertical growth of GP might be affected by progesterone exposure.

Additionally, it is interesting to note that normal pancreatic islet cells also showed positive reactivity for the progesterone receptor. It has been reported that normal pancreatic islet cells and pancreatic neuroendocrine tumors showed positive reactivity for the progesterone receptor [49], and our literature survey demonstrated that epithelioid cells showed a high positive rate for PP $(89.7 \%, 70 / 78)$ immunohistochemically. These facts indicate the relationship between GP and pancreatic islet cells. However, immunohistochemical evaluation for estrogen receptors differs between epithelioid cells and normal pancreatic islet cells, and our immunohistochemical evaluation was based on only one patient. Furthermore, it is strongly suspected that our data have been affected by publication bias.

To confirm these hypotheses, further investigation is required (e.g. compare the positivity between the metastatic cases $[6,24,25,36,46,50-56]$ and non-metastatic cases for the immunohistochemical antigen expression).

\section{Conclusion}

Our literature survey revealed that there were many more cases of GP exceeding the submucosal layer than were expected, and significant differences were found in gender between GP within the submucosal layer and exceeding the submucosal layer. Furthermore, our immunohistochemical evaluation showed that both epithelioid cells and normal pancreatic islet cells showed strongly positive reactivity for progesterone receptors. These immunohistochemical results support the following two hypotheses. First, vertical growth of GP might be affected by progesterone exposure. Second, the origin of GP might be the pancreatic islet cells. However, further investigation is required to confirm these hypotheses.

\section{Consent}

Since the data of this study were extracted and sampled from previous publications, written informed consent for publication from patients does not exist with the exception of our previous publication. As for our previously reported cases, written informed consent was obtained from the patients for publication of this study as well as any accompanying images. A copy of the written consent is available for review by the Editor-in-Chief of this journal. Furthermore, the anonymity of all patients was strictly protected.

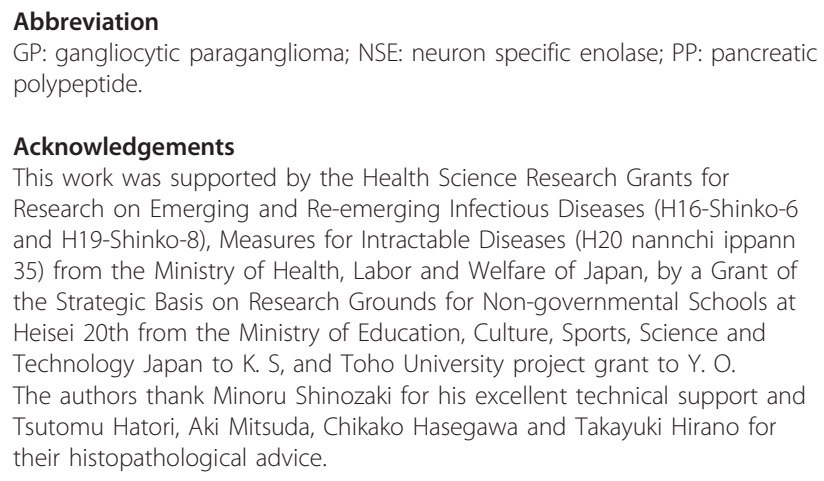

Acknowledgements

This work was supported by the Health Science Research Grants for Research on Emerging and Re-emerging Infectious Diseases (H16-Shinko-6 and H19-Shinko-8), Measures for Intractable Diseases (H2O nannchi ippann 35) from the Ministry of Health, Labor and Welfare of Japan, by a Grant of the Strategic Basis on Research Grounds for Non-governmental Schools at Heisei 20th from the Ministry of Education, Culture, Sports, Science and Technology Japan to K. S, and Toho University project grant to Y. O. The authors thank Minoru Shinozaki for his excellent technical support and Tsutomu Hatori, Aki Mitsuda, Chikako Hasegawa and Takayuki Hirano for their histopathological advice. 


\section{Author details}

'Department of Surgical Pathology, Toho University School of Medicine, 611-1 Omori-Nishi, Ota-Ku, Tokyo, 143-8541, Japan. ${ }^{2}$ Department of Neurosurgery, Toho University Ohashi Medical Center, 2-17-6, Ohashi, Meguro, Tokyo, 153-8515, Japan. ${ }^{3}$ Department of Pathology, Kanagawa Cancer Center, 1-1-2, Nakao, Asahi-Ku, Yokohama-city, Kanagawa, 245-0815, Japan. ${ }^{4}$ Division of General and Gastroenterological Surgery, Department of Surgery (Omori), Toho University School of Medicine, 6-11-1 Omori-Nishi, Ota-Ku, Tokyo, 143-8541, Japan.

\section{Authors' contributions}

YO conceptualized this study, integrated the data, and wrote the manuscript as a major contributor; MY carried out the histopathological evaluation and revised the manuscript; TN carried out statistical evaluation and revised the manuscript; KK and HN carried out statistical evaluation; KS gave final approval to the manuscript as a corresponding author; TY, MY, KS, DS, and TI sampled publications and extracted raw data from English and Japanese publications and integrated the data; MT advised the first author on gangliocytic paraganglioma as a clinical doctor; $\mathrm{NH}$ carried out histopathological and statistical evaluation and revised the manuscript as a last author. All authors contributed to conceptualizing and writing this study. Furthermore, all authors read and approved the final manuscript.

\section{Competing interests}

Dr. Shibuya reports receiving research grants from Pfizer Inc., Janssen Pharmaceutical K.K., and Dainippon Sumitomo Pharma Co. All authors declare that they have no competing interests.

Received: 24 September 2010 Accepted: 20 May 2011 Published: 20 May 2011

\section{References}

1. Dahl EV, Waugh JM, Dahlin DC: Gastrointestinal ganglioneuromas; brief review with report of a duodenal ganglioneuroma. Am J Pathol 1957, 33:953-965.

2. Kepes JJ, Zacharias DL: Gangliocytic paragangliomas of the duodenum. A report of two cases with light and electron microscopic examination. Cancer 1971, 27:61-7.

3. Guarda LA, Ordonez NG, del Junco GW, Luna MA: Gangliocytic paraganglioma of the duodenum: an immunocytochemical study. Am J Gastroenterol 1983, 78:794-798.

4. Perrone T, Sibley RK, Rosai J: Duodenal gangliocytic paraganglioma. An immunohistochemical and ultrastructural study and a hypothesis concerning its origin. Am J Surg Pathol 1985, 9:31-41.

5. Burke AP, Helwig EB: Gangliocytic paraganglioma. Am J Clin Pathol 1989, 92:1-9.

6. Okubo Y, Yokose T, Tuchiya M, Mituda A, Wakayama M, Hasegawa C, Sasai D, Nemoto T, Shibuya K: Duodenal gangliocytic paraganglioma showing lymph node metastasis: A rare case report. Diagn Pathol 2010, 5:27.

7. Lerman Rl, Kaplan ES, Daman L: Ganglioneuroma-paraganglioma of the intradural filum terminale. Case report. J Neurosurg 1972, 36:652-658.

8. Llena JF, Wisoff HS, Hirano A: Gangliocytic paraganglioma in cauda equina region, with biochemical and neuropathological studies. Case report. J Neurosurg 1982, 56:280-282.

9. Djindjian $M$, Ayache $P$, Brugières $P$, Malapert $D$, Baudrimont $M$, Poirier J: Giant gangliocytic paraganglioma of the filum terminale. Case report. $J$ Neurosurg 1990, 73:459-461.

10. Vural M, Arslantas A, Isiksoy S, Adapinar B, Atasoy M, Soylemezoglu F: Gangliocytic paraganglioma of the cauda equina with significant calcification: first description in pediatric age. Zentralbl Neurochir 2008, 69:47-50.

11. Sinkre $P$, Lindberg G, Albores-Saavedra J: Nasopharyngeal gangliocytic paraganglioma. Arch Pathol Lab Med 2001, 125:1098-1100.

12. Hironaka M, Fukayama M, Takayashiki N, Saito K, Sohara Y, Funata N: Pulmonary gangliocytic paraganglioma: case report and comparative immunohistochemical study of related neuroendocrine neoplasms. Am J Surg Pathol 2001, 25:688-693.

13. Kee AR, Forrest CH, Brennan BA, Papadimitriou JM, Glancy RJ: Gangliocytic paraganglioma of the bronchus: a case report with follow-up and ultrastructural assessment. Am J Surg Pathol 2003, 27:1380-1385.
14. Paláu MA, Merino MJ, Quezado M: Corticotropin-producing pulmonary gangliocytic paraganglioma associated with Cushing's syndrome. Hum Pathol 2006, 37:623-626.

15. Reed RJ, Caroca PJ Jr, Harkin JC: Gangliocytic paraganglioma. Am J Surg Pathol 1977, 1:207-216.

16. Aung W, Gallagher HJ, Joyce WP, Hayes DB, Leader M: Gastrointestinal haemorrhage from a jejunal gangliocytic paraganglioma. J Clin Patho 1995, 48:84-85.

17. Weinrach DM, Wang KL, Blum MG, Yeldandi AV, Laskin WB: Multifocal presentation of gangliocytic paraganglioma in the mediastinum and esophagus. Hum Pathol 2004, 35:1288-1291.

18. Harries K, Nunn T, Shah V, Richards D, Manson JM: First reported case of esophageal paraganglioma. A review of the literature of gastrointestinal tract paraganglioma including gangliocytic paraganglioma. Dis Esophagus 2004, 17:191-195.

19. van Eeden S, Offerhaus GJ, Peterse HL, Dingemans KP, Blaauwgeers $\mathrm{HL}$ : Gangliocytic paraganglioma of the appendix. Histopathology 2000 36:47-49.

20. de Montpréville VT, Mussot S, Gharbi N, Dartevelle P, Dulmet E: Paraganglioma with ganglioneuromatous component located in the posterior mediastinum. Ann Diagn Pathol 2005, 9:110-114.

21. Tomic S, Warner T: Pancreatic somatostatin-secreting gangliocytic paraganglioma with lymph node metastases. Am J Gastroenterol 1996, 91:607-608.

22. Mahdavi A, Silberberg B, Malviya VK, Braunstein AH, Shapiro J: Gangliocytic paraganglioma arising from mature cystic teratoma of the ovary. Gynecol Oncol 2003, 90:482-485.

23. Kawaguchi K, Takizawa T, Koike M, Tabata I, Goseki N: Multiple paraganglioneuromas. Virchows Arch A Pathol Anat Histopathol 1985, 406:373-380

24. Dookhan DB, Miettinen M, Finkel G, Gibas Z: Recurrent duodenal gangliocytic paraganglioma with lymph node metastases. Histopathology 1993, 22:399-401.

25. Wong A, Miller AR, Metter J, Thomas CR Jr: Locally advanced duodenal gangliocytic paraganglioma treated with adjuvant radiation therapy: case report and review of the iterature. World J Surg Oncol 2005, 3.

26. Scheithauer BW, Nora FE, LeChago J, Wick MR, Crawford BG, Weiland LH, Carney JA: Duodenal gangliocytic paraganglioma. Clinicopathologic and immunocytochemical study of 11 cases. Am J Clin Pathol 1986, 86:559-565.

27. Hayashi K, Kuroda M, Mizoguchi M: A case of duodenal gangliocytic paraganglioma. Official Journal of the Japanese Association of Pathologists 1994, 12:45, (In Japanese).

28. Ohya M, Utsunomiya S, Yao T: A case of gangliocytic paraganglioma. Official Journal of the Japanese Association of Pathologists 1996, 14:6, (In Japanese).

29. Miyaji J, Kuriyama A, Hiraoka J, Matsuo N, Kawamuwa H, Kawamura H, Ishikawa M, Abe K, Ohmoto M, Tamaru M, Nishina K, Umeda M, Kurokawa T, Ishikawa M: A case of duodenal gangliocytic paraganglioma. Stomach and Intestine 2000, 35:1443-1447, (In Japanese).

30. Nakamura T, Ozawa T, Kitagawa M, Takehira Y, Yamada M, Yasumi K, Tamakoshi K, Kobayashi Y, Nakamura H: Endoscopic resection of gangliocytic paraganglioma of the minor duodenal papilla: case report and review. Gastrointest Endosc 2002, 55:270-273.

31. Hengstler P, Binek J, Meyenberger C: Endoscopic resection of a juxtapapillary gangliocytic paraganglioma. Endoscopy 2003, 35:633-634

32. Nagai T, Torishima R, Nakashima H, Tanahashi J, Iwata M, Ookawara H, Yokoyama S, Yada K, Sato R, Murakami K, Fujioka TJ: Duodenal gangliocytic paraganglioma treated with endoscopic hemostasis and resection. Gastroenterol 2004, 39:277-283.

33. Sánchez-Pobre P, Sáenz-López S, Rodríguez S, Sánchez F, Alemany I, López G, Colina F, Martínez-Montiel P, Marín JC, Castellano G, Solís Herruzo JA: Safe endoscopic resection of gangliocytic paraganglioma of the major duodenal papilla. Rev Esp Enferm Dig 2004, 96:660-664.

34. El Idrissi-Lamghari A, Rioux-Leclercq N, Pagenault M, Bretagne JF: Voluminous juxtapapillary gangliocytic paraganglioma. Gastrointest Endosc 2005, 62:445-446.

35. Chahal P, Prasad GA, Sanderson SO, Gostout CJ, Levy MJ, Baron TH: Endoscopic resection of nonadenomatous ampullary neoplasms. J Clin Gastroenterol 2007, 41:661-666. 
36. Witkiewicz A, Galler A, Yeo CJ, Gross SD: Gangliocytic paraganglioma: case report and review of the literature. J Gastrointest Surg 2007, 11:1351-1354.

37. Loew BJ, Lukens FJ, Navarro F, Roy M, Mattia A, Howell DA: Successful endoscopic resection of a gangliocytic paraganglioma of the minor papilla in a patient with pancreas divisum and pancreatitis (with video). Gastrointest Endosc 2007, 65:547-550.

38. Morita T, Tamura S, Yokoyama Y, Onishi T, Kuratani Y, Mizuta H, Onishi S: Endoscopic resection of a duodenal gangliocytic paraganglioma. Dig Dis Sci 2007, 52:1400-1404.

39. Yamaoka H, Uchida M, Okamoto $K$ : A case of duodenal gangliocytic paraganglioma. Medical Journal of Kochi Health Sciences Center 2007, 2:41-44, (In Japanese).

40. Ishikawa S, Inaba C, Hori K, Wato M, Kawai K: Gangliocytic paraganglioma. Endoscopia Digestiva 2009, 21:1596-1597, (In Japanese).

41. Gal AA, Sheppard MN, Nolen JD, Cohen C: p53, cellular proliferation, and apoptosis-related factors in thymic neuroendocrine tumors. Mod Pathol 2004, 17:33-39.

42. de Krijger RR, van der Harst E, van der Ham F, Stijnen T, Dinjens WN, Koper JW, Bruining HA, Lamberts SW, Bosman FT: Prognostic value of p53, bcl-2, and c-erbB-2 protein expression in phaeochromocytomas. J Pathol 1999, 188:51-55

43. Cadden IS, Atkinson AB, Johnston BT, Pogue K, Connolly R, McCance D, Ardill JE, Russell CF, McGinty A: Cyclooxygenase-2 expression correlates with phaeochromocytoma malignancy: evidence for a Bcl-2-dependent mechanism. Histopathology 2007, 51:743-751.

44. Wang DG, Johnston CF, Sloan JM, Buchanan KD: Expression of BCl-2 in lung neuroendocrine tumours: comparison with p53. J Pathol 1998, 184:247-251.

45. Ohtsuki Y, Watanabe R, Kimura M, Okamoto T, Murakami S, Mizukami Y, Takeji M, Okada Y, Hayashi Y, Lee GH, Furihata M: Immunohistochemical and electron microscopic studies of a case of duodenal gangliocytic paraganglioma. Med Mol Morphol 2009, 42:245-249.

46. Saito J, Hirata N, Furuzono M, Nakaji S, Inase M, Nagano H, Iwata M, Tochitani S, Fukatsu K, Fujii H, Ishii E, Kataoka J, Mikata R, Masuya Y, Ito H, Ohmori J, Wakasugi S, Ebara M, Hoshi K: Nippon Shokakibyo Gakkai Zasshi: A case of duodenal gangliocytic paraganglioma with lymph node metastasis. Nippon Shokakibyo Gakkai Zasshi 2010, 107:639-648, (In Japanese).

47. Bukovsky A, Caudle MR, Svetlikova M: Steroid-mediated differentiation of neural/neuronal cells from epithelial ovarian precursors in vitro. Cell Cycle 2008, 7:3577-3583.

48. Liu L, Wang J, Zhao L, Nilsen J, McClure K, Wong K, Brinton RD: Progesterone increases rat neural progenitor cell cycle gene expression and proliferation via extracellularly regulated kinase and progesterone receptor membrane components 1 and 2. Endocrinology 2009, 150:3186-3196.

49. Alabraba EB, Taniere P, Reynolds GM, Stewart PM, Wigmore SJ, Bramhall SR: Expression and functional consequences of oestrogen and progesterone receptors in human insulinomas. Endocr Relat Cancer 2007, 14:1081-1088.

50. Büchler M, Malfertheiner P, Baczako K, Krautzberger W, Beger HG: A metastatic endocrine-neurogenic tumor of the ampulla of Vater with multiple endocrine immunoreaction-malignant paraganglioma? Digestion 1985, 31:54-59.

51. Inai K, Kobuke T, Yonehara S, Tokuoka S: Duodenal gangliocytic paraganglioma showing lymph node metastasis in a 17-year-old boy. Cancer 1989, 63:2540-2545.

52. Hashimoto S, Kawasaki S, Matsuzawa K, Harada H, Makuuchi M: Gangliocytic paraganglioma of the papilla of Vater with regional lymph node metastasis. Am J Gastroenterol 1992, 87:1216-1218.

53. Takabayashi N, Kimura T, Yoshida M, Sakuramachi S, Harada Y, Kino I: A case report of duodenal gangliocytic paraganglioma with lymph node metastasis. The Japanese Society of Gastroenterological Surgery 1993, 26:2444-2448, (In Japanese).

54. Sundararajan V, Robinson-Smith TM, Lowy AM: Duodenal gangliocytic paraganglioma showing lymph node metastasis: a case report and review of the literature. Arch Pathol Lab Med 2003, 127:139-141.

55. Bucher $P$, Mathe Z, Bühler L, Chilcott M, Gervaz P, Egger JF, Morel P. Paraganglioma of the ampulla of Vater: a potentially malignant neoplasm. Scand J Gastroenterol 2004, 39:291-295.
56. Mann CM, Bramhall SR, Buckels JA, Taniere P: An unusual case of duodenal obstruction-gangliocytic paraganglioma. J Hepatobiliary Pancreat Surg 2009, 16:562-565.

\section{Pre-publication history}

The pre-publication history for this paper can be accessed here: http://www.biomedcentral.com/1471-2407/11/187/prepub

\section{doi:10.1186/1471-2407-11-187}

Cite this article as: Okubo et al:: Literature survey on epidemiology and pathology of gangliocytic paraganglioma. BMC Cancer 2011 11:187.

\section{Submit your next manuscript to BioMed Central and take full advantage of:}

- Convenient online submission

- Thorough peer review

- No space constraints or color figure charges

- Immediate publication on acceptance

- Inclusion in PubMed, CAS, Scopus and Google Scholar

- Research which is freely available for redistribution 